Eva Csipak

University of Konstanz ${ }^{* *}$

\title{
CONDITIONAL ANTECEDENTS CONTAINING THE GERMAN DISCOURSE PARTICLE DENN: A CORPUS STUDY***
}

\section{INTRODUCTION}

The German expression denn has various functions, for example, as a sentence connector, as a comparative particle, and notably as a discourse particle. The literature on discourse particle denn nearly exclusively discusses its use in questions (see Thurmair 1989, 1991; Bayer 2012, i. a.). In this paper, we take a look at a second, understudied use of discourse particle denn, as in (1), which occurs in the antecedent of a conditional (henceforth: conditional denn; see Brauße 1994; Kwon 2005; Coniglio 2011; Häussler 2015).

(1) [Context: A asks B which activities are planned for the next day.]

B: Wir gehen schwimmen, wenn es denn warm genug ist. we go swimming if it DENN warm enough is

B: 'We'll go swimming, if it is DENN warm enough.'

By using conditional denn, B signals that she is uncertain, even skeptic, that it will be warm enough to go swimming the next day. Hence, denn intuitively strengthens the pragmatic inference connected to the antecedent ${ }^{1}$ that the speaker does not believe that the proposition denoted by the antecedent (i.e., the "antecedent proposition") holds.

The aim of this paper is to present two corpus studies that shed light on one of the conditions of use of conditional denn by exploring the behavior of antecedents containing denn (henceforth: AWD), and to discuss a classification of the corpus data based on observations from the studies.

\footnotetext{
* sarah.zobel@ds.uni-tuebingen.de

** eva.csipak@uni-konstanz.de

*** We thank Edith Scheifell for bringing the use of the particle denn in conditionals to our attention. We also thank Andrea Beltrama, María Biezma, Ryan Bochnak, Kai von Fintel, Viola Schmitt, Frank Sode, Yvonne Viesel, Thomas Weskott, and the audiences at CSSP 2015, SinFonIJA 8, Questions in Discourse 7, and María Biezma's course "Pragmatics 3" (Konstanz, Summer 2016) for helpful discussion. We also thank an anonymous reviewer for comments on the manuscript. All mistakes are our own.

1 For the sake of brevity, whenever we use the term "antecedent", we mean conditional antecedents.
} 
The paper is structured as follows. We briefly present the existing literature on conditional denn and introduce our own account of conditional denn's conditions of use and semantic contribution in Section 2. In Section 3, we present the results of our corpus studies on the behavior of AWDs and discuss their implications. The classification of the corpus data is presented in Section 4. Section 5 concludes.

\section{A SEMANTIC/PRAGMATIC ANALYSIS OF CONDITIONAL DENN}

\subsection{The Function of Discourse Particles and Previous Analyses of Conditional denn}

The function of discourse particles is to fit the current utterance to the ongoing discourse (Zimmermann 2011). That is, they convey speaker attitudes or additional information on the content of that utterance. In this sense, they are "discourse navigating devices" (see McCready 2006; Eckardt 2013; Rojas-Esponda 2014) that are utilized by the speaker to make explicit certain parts of the discourse, for instance, the make-up of the current "common ground" (= the beliefs the speaker and her addressee share as a result of their conversation, Stalnaker 1973). It is commonly assumed that formally, discourse particles contribute "not-at-issue content", that is, content that is not part of the truth conditions of the sentence that contains the particles (see Simons et al. 2011; Potts 2015).

As we have stated in the introduction, conditional denn is understudied compared to denn in questions. ${ }^{2}$ In the literature, conditional denn is discussed in Brauße 1994, Kwon 2005, Coniglio 2011, and Häussler 2015. Differing in the details, these authors agree that conditional denn seems to signal the speaker's uncertainty or doubt about the truth of the antecedent proposition. While intuitively appealing, this leaves open the question as to how the contribution of denn differs from and interacts with the inference connected to the antecedent that the speaker is not committed to the truth of the antecedent in the actual world. Our proposal, which we give below, is completely explicit regarding this point.

\subsection{A New Analysis of Conditional denn}

Below, we summarize our own analysis of the conditions of use and the semantic contribution of conditional denn. For reasons of space, we cannot fully motivate and discuss our analysis; for details, we refer the interested reader to Csipak and Zobel (to appear).

The three parts of our proposal in (2)-(4) are based on our native speaker intuitions regarding constructed examples and a sample of naturally occurring data taken from the ZEIT corpus from the online platform "Digitales Wörterbuch der Deutschen Sprache" ("Digital Dictionary of the German Language", DWDS).

2 Discourse particle denn in questions has been discussed quite extensively while conditional denn has been mostly overlooked. This is not surprising given the relative frequency of the two uses: compared to denn in questions, conditional denn is rare; the latter use makes up only about 3-5\% of all particle uses. This estimate is based on a random sample of 200 tokens of denn exported from the corpus of Spoken German ("Gesprochene Sprache", 2.5 million tokens) that is part of the DWDS platform (export: Jan. 30, 2016). For reasons of space, the details of this study cannot be presented. 
The first condition of use for conditional denn given in (2) captures that denn can only be used if the speaker is uncommitted to the truth of the proposition $p$ that denn comments on.

\section{(2) Condition 1}

The speaker does not believe that $p$ is true in the actual world $w_{0}$, that is, he is uncommitted to the truth of $p$ in $w_{0}$.

Antecedents of hypothetical conditionals fulfill this condition while antecedents of temporal and factual conditionals do not (see Fabricius-Hansen and Sæbø 1983; von Fintel 2011). Above, we observed that conditional denn makes explicit the speaker's uncertainty regarding the antecedent proposition $p$ for the antecedent in which it occurs. When is a speaker prompted to express uncertainty or doubt with respect to a proposition $p$ ? For example, when there is evidence in the discourse context that someone acts as if $p$ were true, but the truth of $p$ is not supported by the speaker's knowledge about the actual world. Condition 2 restricts the use of denn to a subtype of this kind of context: the proposition $p$ on which denn comments must have been tacitly proposed. ${ }^{3}$

(3) Condition 2

The proposition $p$ is tacitly proposed or can reasonably be inferred to be tacitly proposed by a participant $\alpha$, where $p$ is a necessary precondition for the validity of the content of a previous utterance by $\alpha$ (or a part of that utterance). ${ }^{4}$

Any non-explicitly conveyed content qualifies as a tacit proposal. The term "necessary precondition" is not meant in a logical sense; it includes presuppositions, as well as premises of defeasible inferences based on world knowledge. In sum, the concept of "tacitly proposed necessary precondition" is a generalization of the notion of presupposed new information. This is information that the speaker asks the addressee to accommodate before regular discourse updates can be performed (see von Fintel 2008).

Lastly, we assume that the not-at-issue content contributed by the particle interacts with the pragmatic inference accompanying the use of a hypothetical conditional: the speaker is uncommitted to the truth of the antecedent proposition $p$ in $w_{0}$ (as required by Condition 1). By adding denn, the speaker signals that she is not only uncommitted to the truth of $p$, but in fact judges $p$ as so improbable that she would not be willing to assert it.

(4) Not-at-issue content contributed by denn.

$[[\text { denn }]]^{\mathrm{c}}(\mathrm{p}): \operatorname{prob}\left(\mathrm{c}_{\mathrm{s}}, \mathrm{w}_{0}, \mathrm{p}\right)<\mathrm{T}$,

where $\mathrm{T}$ is the threshold for assertability

In prose: The probability assigned by the speaker $\mathrm{c}_{\mathrm{S}}$ to whether $p$ is true in $w_{0}$ is less than a pragmatic assertability threshold $\mathrm{T}$.

3 Condition 2 also excludes denn from occurring in factual conditionals.

4 Note that $\alpha$ can also be the speaker. 
Example (5) illustrates the entire proposal.

(5) [Context: Speaker A discusses his first visit to his fiancé's brother with a friend.] A: Sein Auto habe ich nicht gesehen, wenn er denn eines hat. his car have I not seen if he DENN one has A: 'I didn't see his car, if he DENN has one.'

Condition 1 is met because denn occurs in the antecedent of a hypothetical conditional. Condition 2 is also met. The definite description sein Auto (Engl. 'his car') in the consequent presupposes that A's fiancé's brother has a car $(=p)$. Since it is A's first visit to the brother's house, the presupposed content $p$ is plausibly not part of the common ground. Hence, by using the definite description, A makes the tacit proposal to update the common ground with 'He has a car'. Lastly, the use of conditional denn signals that speaker A is uncertain/skeptic that his fiancé's brother has a car, and that he is, hence, unwilling to assert or to presuppose $p$.

While Condition 1 captures a precise property of conditional denn, the exact nature of Condition 2 raises more questions. To gain a clearer empirical picture, we conducted two corpus studies to investigate whether there is evidence for the presence of a preceding tacit proposal. The results are presented in Section 3.

\section{CORPUS STUDIES ON CONDITION 2}

\subsection{Study 1}

\subsubsection{Operationalization}

The obvious problem with finding an adequate operationalization for pragmatic concepts like "presence of a tacit proposal" is how to translate them into categories that can be reliably and potentially automatically checked for in a sample of corpus data. The operationalization that we use in our first study is "position of the antecedent relative to its consequent". While the items cannot be tagged automatically for this property, reliable annotation criteria can be given easily.

The motivation for this choice is the following observation: If a speaker uses AWDs to express uncertainty with respect to a tacit proposal made by her interlocutor, our intuition is that she preferably uses a bare antecedent. In contrast, if the speaker uses an AWD to self-qualify her own statements, she preferably uses a full conditional where the tacit proposal occurs in the consequent.

(6) Exploratory hypothesis 1

Antecedents containing denn in full conditionals occur more frequently following an overt consequent than preceding it. ${ }^{5}$

5 The conditions of use for discourse particles are not strict rules (cf. Zimmermann 2011: 2027). Hence, we can only expect to find the predicted patterns regarding Condition 2 in the majority of cases. 


\subsubsection{Choice of Corpus and Query}

We chose the ZEIT corpus available at the DWDS platform. ZEIT is a corpus of journalistic texts $(\sim 225.8$ mio. tokens, 2015) taken from the German weekly newspaper DIE ZEIT, which among traditional articles also contains transcribed interviews (i.e., texts in written language that is close to spoken language), which arguably increases the possibility of encountering discourse particles. To specifically target AWDs, we used the query in (7).

(7) (“wenn \#7 denn”) || (“@falls \#7 denn”) \&\& !(“), denn”) \&\& !(“'; denn”) \&\& !(“।: denn”)

The query includes denn following the conditional subjunctors wenn or falls, and excludes the occurrences of denn introducing an independent clause. ${ }^{6}$ The query (May 3,2015 ) yielded 4,411 results which were all exported. From this sub-corpus, we randomly picked a sample of 300 items, which were filtered manually for false hits and problematic items. ${ }^{7}$ The final number of corpus items that were annotated was 260 .

\subsubsection{Details Regarding the Annotation}

To annotate the relative position of the antecedent, we used the two field categories "Vorfeld" and "Nachfeld" of the classical Topological Field Model (see Höhle 1986): the "Vorfeld" contains the linguistic material before the finite verb in German main clauses; the "Nachfeld" contains the material after the non-finite verbal material in main clauses and all verbal material in embedded clauses. In addition to these categories, we used the levels "bare" for bare antecedents and "parenthetical" for antecedents that are inserted parenthetically after the Vorfeld constituent or as part of the main body of the sentence (= the "Mittelfeld"). ${ }^{8}$ The latter level was not planned initially, but proved to be necessary during the annotation process. ${ }^{9}$

(8) POSITION OF ANTECEDENT (4 levels)

bare (9a), Vorfeld (9b), parenthetical (9c), Nachfeld (9d)

(9) a) Wenn sie das denn angegeben und öffentlich zugänglich gemacht haben. if they that DENN specified and publicly accessible made have 'If they DENN specified it, and made it publicly accessible.'*

b) Wenn's denn so polar zugehen sollte, dann ziehe ich die USA vor. if-it DENN so polar be-like-this should then prefer I the USA PRT 'If we are DENN supposed to have a strict opinion, then I prefer the US.'*

6 The conjunction denn expresses a causal link between the two conjuncts.

7 Items were classified as problematic if they were fragments, or if it was impossible for us to make sense of the content.

8 In the Nachfeld, AWDs that are semantically embedded and parenthetical AWDs were not distinguished. For the purpose of this study, the distinction is not crucial.

9 Examples that were taken from the corpus sample (possibly with slight editing) are marked by * after the translation. 
c) Aber dazu war Neuber, wenn er denn gewollt hätte, gar nicht in der Lage. but to-this was Neuber if he DENN wanted had at-all not in the position 'But Neuber was not in the position to do this if he would DENN have wanted to.'*

d) Ein Handy, mit dem man alles kann, wenn man es denn könnte. a cell-phone with which one everything can if one it DENN could

'A cell phone with which you can do everything if you are DENN able to.'*

We annotated the 260 items independently using the criteria above; we achieved a percentage of agreement of $91.9 \%(\kappa=0.88)$. In a second step, we discussed the items for which we had disagreed in our separate annotations and decided on a final annotation for the quantitative evaluation.

\subsubsection{Results and Discussion}

The frequencies of the four levels of POSITION OF ANTECEDENT found in the sample are given in Table 1; the relative frequencies are illustrated in Figure 1.

Table 1: Frequencies POSITION OF ANTECEDENT - AWDs

\begin{tabular}{|l|l|l|l|l|}
\cline { 2 - 5 } \multicolumn{1}{c|}{} & BARE & VORFELD & PARENTHETICAL & NACHFELD \\
\hline FREQUENCIES & $14(5.4 \%)$ & $50(19.2 \%)$ & $110(42.3 \%)$ & $86(33.1 \%)$ \\
\hline
\end{tabular}

The frequencies of the four levels differ significantly $\left(\chi^{2}=81.42, \mathrm{df}=3, \mathrm{p}<0.05\right)$; the direct comparison of the levels "Vorfeld" and "Nachfeld" also reveals a statistically significant difference $\left(\chi^{2}=9.53, \mathrm{df}=1, \mathrm{p}<0.05\right)$. Hence, the data support our hypothesis.

Figure 1: Relative frequencies POSITION OF ANTECEDENT - with denn

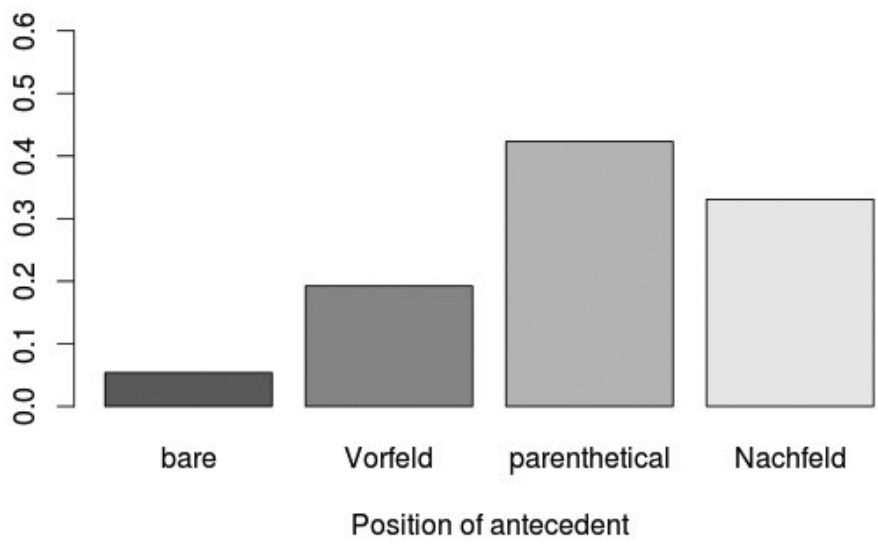


The high number of parenthetical AWDs was not anticipated. Parenthetical AWDs come with the additional complication that the relative position with respect to the tacit proposal given in the consequent has to be determined on a case-by-case basis. This means that the placement of an AWD relative to the consequent cannot be used as a heuristic for the relative position of the AWD and the tacit proposal. Since parenthetical AWDs form the largest group, our original operationalization is less reliable than we initially assumed. A different method was chosen for Study 2.

Given the surprising amount of parenthetical AWDs, we investigated whether antecedents of hypothetical conditionals in general behave like AWDs regarding their syntactic positions. We annotated 100 items of hypothetical conditionals (ZEIT corpus, DWDS) for the same factor and levels (agreement: $98 \%, \kappa=0.96$ ). The result is given in Table 2 and Figure $2 .{ }^{10}$

Table 2: Frequencies of POSITION OF ANTECEDENT - hyp. conditionals

\begin{tabular}{|l|l|l|l|l|}
\cline { 2 - 5 } \multicolumn{1}{c|}{} & BARE & VORFELD & PARENTHETICAL & NACHFELD \\
\hline FREQUENCIES & $0(0 \%)$ & $48(48 \%)$ & $3(3 \%)$ & $49(49 \%)$ \\
\hline
\end{tabular}

Figure 2: Relative frequencies of POSITION OF ANTECEDENT - hyp. conditionals

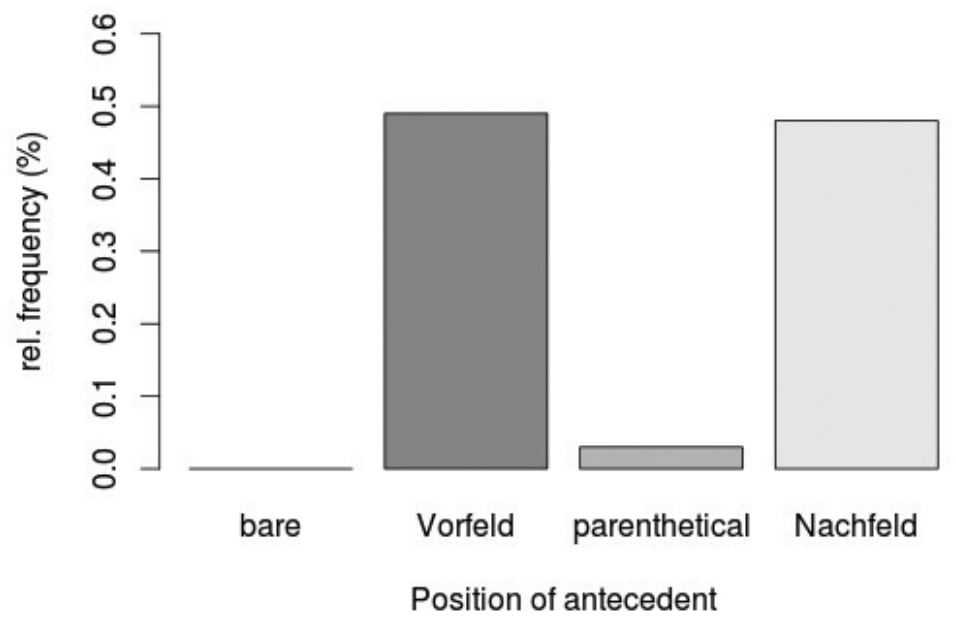

A direct comparison of Figure 1 and Figure 2 clearly shows that AWDs behave quite differently from antecedents of regular hypothetical conditionals. This suggests that there is indeed a factor that influences placement of AWDs. We argue that this factor is the presence of a preceding tacit proposal to which conditional denn is sensitive.

10 Our study reproduces the results in Volodina (2014: 756ff). 
Taking a closer look at the placement of a handful of parenthetical cases, we also observed that AWDs are preferably placed as close to the perceived source of the proposal as (syntactically) possible. This is further supported by the descriptive results of Study 2 .

\subsection{Study 2}

\subsubsection{Items and Operationalization}

Since the first syntactic operationalization was shown to lack the necessary precision, we chose to annotate the same sample items as in Study 1 (based on our informed native speaker intuitions) regarding the relative positions of the AWD and the material that we identify as the source of the tacit proposal: ${ }^{11}$

(10) Exploratory hypothesis 2

Antecedents containing denn more often follow the source of the tacit proposal than precede it.

\subsubsection{Details Regarding Annotation}

We annotated two factors, RELATIVE POSITION OF PROPOSAL and PROPOSAL IN SENTENCE. The levels of the first factor answer the question "Where does the tacit proposal originate in the discourse relative to the position of the AWD?" The final set of levels for this factor was determined during the annotation process.

(11) RELATIVE POSITION OF PROPOSAL (5 levels)

before, around, after, inside, indeterminable

The levels "before" (12) and "after" (13) encode the following: in case we could identify the lexical material to which we could ascribe the source of the tacit proposal, this material (inside the preceding context or the item itself) was entirely before or after the AWD. ${ }^{12}$

Ein Handy, mit dem man alles kann, wenn man es denn könnte. a cell-phone with which one everything can if one it DENN could 'A cell phone with which you can do anything if you are DENN able to.'*

Wenn sie denn nicht vermeidbar ist, wie sollte eine Kündigung kommuniziert werden? if she DENN not avoidable is how should a termination communicated become 'If it is DENN not avoidable, how should a termination be communicated?'*

11 We are aware of the problems connected with annotating non-objective properties of data. We believe, however, that new insights can be gained this way, nevertheless, given the exploratory nature of this study and adequate caution.

12 The lexical source material of the tacit proposal which we identified is underlined. 
The level "around" (14a) was assigned to items for which the lexical source material was partly before and after the antecedent; the level "inside" (14b) was given to items for which the antecedent explicitly repeated (part of) the lexical source material.

a) Wohin aber soll sich die Partei, wenn sie es denn überhaupt will, wenden? where but shall SELF the party if she it DENN at-all wants turn-to 'But which new orientation should the party choose if it DENN wants to'*

b) Und wenn es denn ein Vorwurf sein sollte, er sei ja ein deutscher Patriot... and if it DENN a reproach be should he is PRT a German patriot 'And if it should DENN be a reproach that he is a German patriot..."*

Lastly, the level "indeterminable" was used for items for which no plausible lexical source material could be determined inside the preceding context (one sentence) or the item itself.

The factor REL. POSITION OF PROPOSAL does not encode information about whether the source of the proposal can be found in the item or the preceding context. Hence, we annotated the second factor PROPOSAL IN SENTENCE. Its two levels are the answers to the question "Is there evidence that the tacit proposal originates inside the conditional?" The level "yes" is illustrated, for instance, in (12), "no" is illustrated in (16).

(15) PROPOSAL IN SENTENCE (2 levels): yes, no

Da blieben kaum Wünsche offen. Das heißt: Wenn man sich das Gerät denn there stay hardly wishes open this means if one SELF the device DENN leisten konnte.

afford could

'Hardly any wish was left unfulfilled. That is, if one could DENN afford the device.'*

Again, we first annotated the items independently; we achieved a percentage of agreement of $65.8 \%$ for the first factor $(\kappa=0.34)$ and of $75.4 \%$ for the second factor $(\kappa=0.45) .{ }^{13}$ The items for which we had disagreed were discussed to decide on an annotation; if no clear answer could be found for the first factor, we annotated the item as "indeterminable".

13 Given the nature of the factors, values of $\kappa$ of this magnitude are expected (Artstein \& Poesio 2008). 


\subsubsection{Results}

Tables and Figures 3-4 show the absolute and relative frequencies for the two factors.

Table 3: Frequencies of REL. POSITION OF PROPOSAL

\begin{tabular}{|l|l|l|l|l|l|}
\cline { 2 - 6 } \multicolumn{1}{c|}{} & BEFORE & AROUND & AFTER & INSIDE & INDETERMINABLE \\
\hline FREQUENCIES & $168(64.6 \%)$ & $25(9.6 \%)$ & $14(5.4 \%)$ & $9(3.5 \%)$ & $44(16.9 \%)$ \\
\hline
\end{tabular}

Table 4: Frequencies of PROPOSAL IN SENTENCE

\begin{tabular}{|l|l|l|}
\cline { 2 - 3 } \multicolumn{1}{c|}{} & YES & No \\
\hline FREQUENCIES & $176(67.7 \%)$ & $84(32.3 \%)$ \\
\hline
\end{tabular}

Figures 3-4: Rel. frequencies REL. POSITION OF PROPOSAL \& PROPOSAL IN SENTENCE

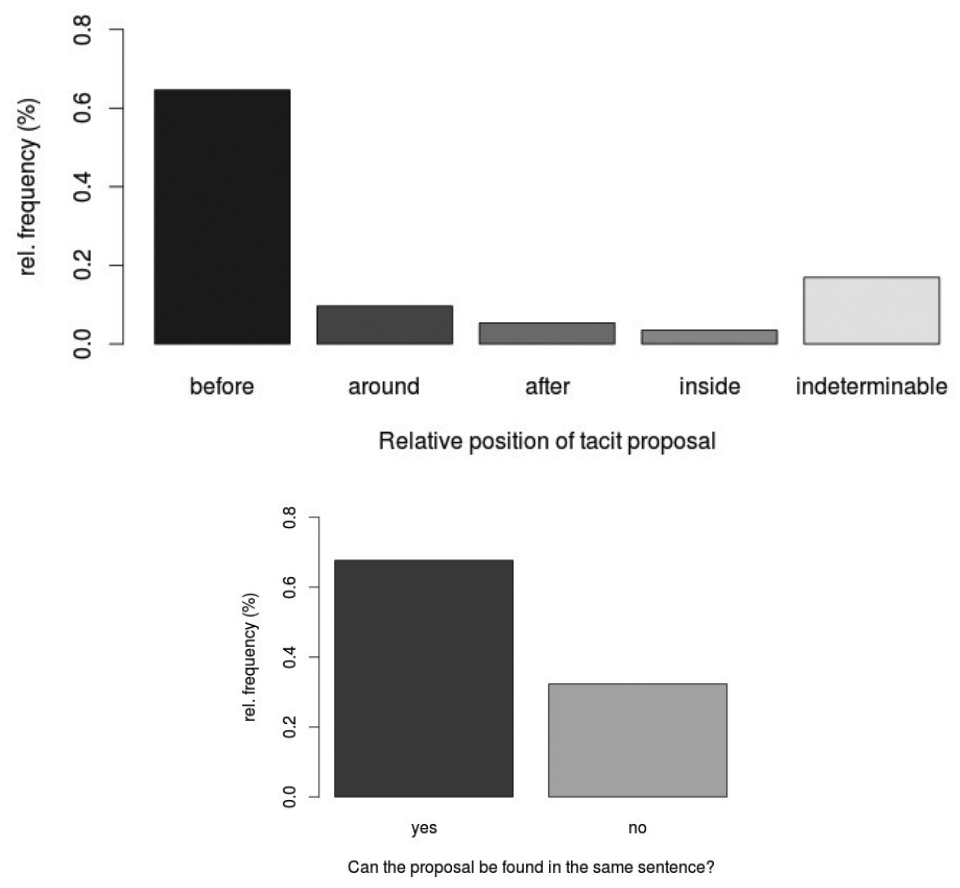

We did not anticipate the existence of the levels "around" and "inside" for REL. POSITION OF PROPOSAL when we formulated the hypothesis in Section 3.2.1. To stay conservative with respect to our hypothesis, we grouped these two levels with 
"indeterminable" and "after" for the statistical tests. A $\chi^{2}$-test on this grouping showed that the difference between the level "before" (168 items) and the group containing all other levels (92 items) is statistically significant $\left(\chi^{2}=22.22, \mathrm{df}=1, \mathrm{p}<0.05\right)$. Hence, the findings support our hypothesis.

The interaction between the above two factors and POSITION OF ANTECEDENT (Study 1) provides further insights. Items annotated with the levels "around", "after", and "inside" (REL. POSITION OF PROPOSAL) were predictably only assigned the level "yes" for PROPOSAL IN SENTENCE. For the level "before", we find both levels: 128 items "yes" (76.2\%) and 40 items "no" (23.8\%). At the end of Section 3.1.4., we reported the observation that AWDs seem to be positioned as close to the lexical source material of the tacit proposal as possible. If this is indeed the case, we would expect-for the 40 proposals that precede the AWD ("before", REL. POSITION OF PROPOSAL), but are not in the same sentence ("no", PROPOSAL IN SENTENCE) to find that a majority of these AWDs are either bare or in the Vorfeld (POSITION OF ANTECEDENT). This is borne out, compare Table 5 and Figure 5 to the results in Study 1.

Table 5: Frequencies for POSITION OF ANTECEDENT - items annotated for a preceding proposal that is not in the same sentence as the antecedent

\begin{tabular}{|l|l|l|l|l|}
\cline { 2 - 5 } \multicolumn{1}{c|}{} & BARE & VORFELD & PARENTHETICAL & NACHFELD \\
\hline FREQUENCIES & $10(25 \%)$ & $17(42.5 \%)$ & $6(15 \%)$ & $7(17.5 \%)$ \\
\hline
\end{tabular}

Figure 5: Rel. frequencies for POSITION OF ANTECEDENT - items annotated for a preceding proposal that is not in the same sentence as the antecedent

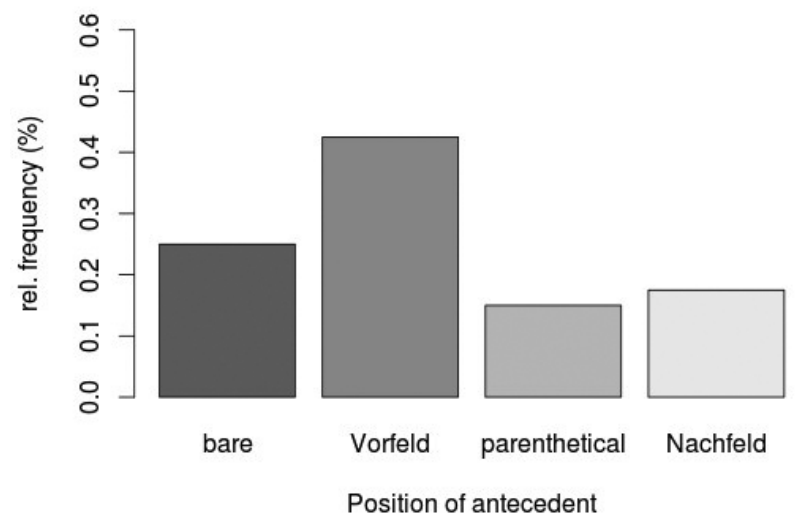




\subsection{Summary}

Study 1 suggests that some factor (i.e., the presence of conditional denn) affects the syntactic placement of AWDs, which preferably occur parenthetically or in the Nachfeld. Our intuitive analysis of the relative position of the lexical source material of the tacit proposals in Study 2 suggests that this material generally precedes the AWD, as is predicted by Condition 2 (see Section 2.2). In addition, the interaction between the factors annotated in the two studies supports the hypothesis that the AWD follows the lexical source material as closely as syntactically possible.

\section{CLASSES OF TACIT PROPOSALS}

During the annotation process for Study 2, we noticed patterns regarding certain classes of tacit proposals. The two main classes of tacit proposals can be distinguished by their origin: proposals made by the speaker and proposals made by others. A third class contains cases that are potentially problematic for which the source of the tacit proposal cannot be identified.

\subsection{Proposals Made by the Speaker}

In the majority of cases, the speaker uses an AWD to qualify her own statements (possibly due to the genre we investigated). We can distinguish the following subclasses.

\section{1) Existence presupposition of a determiner phrase (DP)}

The largest individual subclass of tacit proposals are cases like (17), where the speaker uses a definite DP in the consequent, and then inserts an AWD to signal that the existence presupposition triggered by the DP may not hold.

Blatter soll besser die Fakten auf den Tisch legen, wenn er denn welche hat. Blatter shall better the facts on the table lay if he DENN some has 'Blatter had better present the facts if he DENN has any.'*

In the consequent of (17), the speaker tacitly proposes (or at least assumes) that Blatter possesses "the facts"; otherwise it would not be reasonable to demand that he presents them. The antecedent serves to highlight this assumption and to call it into question.

\section{2) Metacomment}

A second class of self-qualifying uses of AWDs is those examples where the speaker adds an antecedent to reflect on word choice, as in (18).

Grundsätzlich aber hat Angela Merkel eine Eigenschaft, wenn man es denn
basically but has Angela Merkel a trait if one it DENN
so nennen will, die mancher Politiker gerne hätte.
so call want that many politician gladly had


'But basically, Angela Merkel has a trait, if you DENN want to call it that, which many politicians would like to have.'*

Through the use of the AWD in (18), the speaker qualifies her use of the term "trait" in the consequent, which tacitly proposes that the speaker would "call it that". The AWD also signals the speaker's willingness to change her wording.

3) Qualification of a precondition of a modal

For conditionals containing overt modals in the consequent, the antecedent proposition $p$ is usually assumed to restrict the modal base of the modal (see Kratzer 2012). AWDs sometimes contain another modal (or attitudinal) proposition that comments on the modal in the consequent, as in (19).

Auch bei einem überprüften Lehrplan könnten Lehrer immer noch-wenn sie es also with a checked curriculum could teachers always still if they it denn wollten-ihre ganz eigene Sichtweise des Islams vermitteln.

DENN wanted their completely own view of-the Islam convey

'After the curriculum has been checked, teachers could still - if they DENN wanted to convey their very own view of Islam.'*

The consequent conveys that in view of what the law provides, teachers are allowed to convey their own view of Islam. The speaker, we assume, qualifies her statement by making explicit a tacit assumption suggested by könnten (Engl. 'could'), namely that the teachers actually want to do this. That is, deontic possibility regarding an action only becomes an issue if a wish to perform the action exists.

Since the modal and the dependent infinitive (underlined in (19)) are positioned at the two ends of the German Mittelfeld (see Section 3.1.3), the material providing the tacit proposal usually surrounds a parenthetical antecedent (= level "around", Study 2).

\subsection{Proposals Made by Others}

The second class of tacit proposals are cases in which the speaker is explicitly arguing against the assumptions that are not her own. In many cases, these assumptions are treated as "established knowledge" by others (i.e., as part of the common ground).

[Context: American investors are expecting a change in interest rates and have done so for a long time.]

Einen Überraschungseffekt wie 1987 wird es deshalb nicht geben, a surprise-effect like 1987 will it therefore not give wenn die US-Notenbank denn tatsächlich die Zinswende einläutet. if the US-Federal-Reserve DENN effectively the interest-turn heralds 'That is why there will not be a surprise effect if the Federal Reserve DENN does change the interest rates. '* 
The context preceding (20) establishes that expert investors are expecting the Federal Reserve to change the interest rates. By using an AWD, the speaker conveys that she does not share this expectation and that she is skeptical that it will happen.

Sometimes the proposal against which the speaker argues is mentioned explicitly in a complement clause inside the AWD (= level "inside", Study 2), as in (21).

[Context: An article about the economic status of various EU accession countries.] Wenn es denn zutrifft, dass Ungarn das am höchsten entwickelte Beitrittsland ist, if it DENN is-the-case that Hungary the at-the highest developed accession-country is 'If it is DENN the case that Hungary is the best-developed accession country, $[\ldots]$ '*

Lastly, we got the impression that in some cases, the speaker used an AWD to preemptively argue against something that could be reasonably assumed to be a proposal by somebody else given the topic of discourse.

[Context: The speaker talks about an artist and his current exhibition.]

Wenn es denn schon wieder so weit ist, von den Berliner Künstlern der Szene if it DENN already again so far is about the Berlin artists of-the scene der sechziger und siebziger Jahren bereits als Klassiker zu sprechen [...] of-the sixties and seventies years already as classics to speak 'If it is DENN already time to call the artists of the Berlin scene in the 60s and 70s "classics" $[\ldots]$..*

For these examples, no lexical source material could be identified (= level "indeterminable", Study 2).

\subsection{Frustration Cases}

The frustration cases cannot be clearly classified into one of the two main classes since the question of the origin of the tacit proposal cannot be answered. In these cases, the speaker uses wenn es denn sein muss (Engl. 'if it cannot be helped') to signal frustration with the state of affairs described in the consequent, and expresses uncertainty that this is the only available option, as in (23).

[Context: Intimacy and atmosphere in romantic hotels in the US.]

Das heißt auf Amerikanisch: herzförmige Badewanne, herzförmiges Bett, herzförmige this means on American heart-shaped bath-tub heart-shaped bed heart-shaped Kissen und, wenn's denn sein muß, auch noch herzförmige Fußabstreifer. pillows and if-it den be mustalso else heart-shaped doormats 'In the US, this means: a heart-shaped tub, a heart-shaped bed, heart-shaped pillows, and, if it DENN can't be helped, heart-shaped doormats. * 
It is unclear whether there has been a previous tacit proposal in these cases or whether the antecedent wenn es denn sein muss has become a fixed expression conveying the speaker's frustration about the status quo that does not require a preceding tacit proposal. For reasons of space, this question is left for future work.

\section{CONCLUSION}

We have shown that conditional denn is restricted to those types of conditionals which do not commit the speaker to the truth of the antecedent proposition $p$ (Condition 1), and contributes that the speaker is skeptical of the truth of $p$. AWDs most frequently occur in contexts where they follow a tacit proposal of $p$, as is required by Condition 2 . This explains why AWDs (more so than regular hypothetical antecedents) occur parenthetically or in the Nachfeld. Tacit proposals of $p$ can originate with the speaker or with others. In both cases, an AWD signals that the speaker is not or no longer willing to accept $p$ as true. Hence, conditional denn is a discourse-navigating device (like other discourse particles) that allows the speaker to prevent $p$ from becoming common ground.

\section{References}

ARTSTEIN, Ron/Massimo POESIO (2008) "Inter-coder agreement for computational linguistics." Computational Linguistics 34, 555-596.

BAYER, Josef (2012) "From modal particle to interrogative marker: a study of German denn." In: L. Brug et al. (eds), Functional Heads. Oxford: Oxford University Press, 13-26.

BRAUSSE, Ursula (1994) Lexikalische Funktionen der Synsemantika. Tübingen: Narr.

CSIPAK, Eva/Sarah ZOBEL (to appear) "Discourse particle denn in the antecedent of conditionals." In: C. Piñón (ed.), Empirical Issues in Syntax and Semantics 11. Paris: CSSP. http://www.cssp.cnrs.fr/eiss11/

CONIGLIO, Marco (2011) Die Syntax der deutschen Modalpartikeln (studia grammatica 73). Berlin: Akademie Verlag.

ECKARDT, Regine (2013) "Speaker commentary items." In: 19th ICL papers, Geneva 20-27 July 2013. Unedited online publication.

FABRICIUS-HANSEN, Cathrine/Kjell Johan SÆBØ (1983) "Über das Chamäleon wenn und seine Umwelt." Linguistische Berichte 83, 1-35.

VON FINTEL, Kai (2008) "What is presupposition accommodation again?" Philosophical Perspectives 22/1, 137-170.

VON FINTEL, Kai (2011) "Discourse particles." In: C. Maienborn et al. (eds), Handbooks of Linguistics and Communication Science (HSK) 33/2. Berlin/New York: DeGruyter, 1515-1538.

HÄUSSLER, Jana (2015) "Wenn denn denn lizenziert ist: The German discourse particle denn in conditionals." In: E. Brandner et al. (eds), Webschrift for Josef Bayer, 83-88. http://ling.uni-konstanz.de/pages/WebschriftBayer/2015/contents.html 
HÖHLE, Tilman (1986) "Der Begriff Mittelfeld. Anmerkungen über die Theorie der topologischen Felder." In: W. Weiss et al. (eds), Textlinguistik contra Stilistik? Wortschatz und Wörterbuch - Grammatische oder pragmatische Organisation von Rede? Akten des VII. Internationalen Germanisten-Kongresses, Göttingen 1985. Band 3. Tübingen: Niemeyer, 329-340.

KRATZER, Angelika (2012) Modals and conditionals: New and revised perspectives. Oxford: Oxford University Press.

KWON, Min-Jae (2005) Modalpartikeln und Satzmodus - Untersuchungen zur Syntax, Semantik und Pragmatik der deutschen Modalpartikeln. LMU Munich.

MCCREADY, Eric (2006) "Japanese Yo: Its semantics and pragmatics." Sprache und Datenverarbeitung 30/1, 25-34.

POTTS, Chris (2015) "Presupposition and implicature." In: S. Lappin/C. Fox (eds), The Handbook of Contemporary Semantic Theory. Oxford: Wiley-Blackwell, 168-202. ROJAS-ESPONDA, Tania (2014) “ A discourse model for "überhaupt”." Semantics and Pragmatics 7, 1-45.

SIMONS, Mandy et al. (2011) “What projects and why." In: N. Li/D. Lutz (eds), Proceedings of SALT 20, 309-327. http://dx.doi.org/10.3765/salt.v20i0.2584

STALNAKER, Robert (1973) "Presupposition." Journal of Philosophical Logic 2, 77-96.

THURMAIR, Maria (1989) Modalpartikeln und ihre Kombinationen. Tübingen: Niemeyer.

THURMAIR, Maria (1991) “Zum Gebrauch der Modalpartikel "denn” in Fragesätzen. Eine korpusbasierte Untersuchung." In: E. Klein et al. (eds), Betriebslinguistik und Linguistikbetrieb. Akten des 24. Ling. Koll. Bremen, 377-387.

VOLODINA, Anna (2014) "C4.1 Konditionale Konnektoren." In: E. Breindl et al. (eds), Handbuch der deutschen Konnektoren 2. Semantik der deutschen Satzverknüpfer. Berlin/New York: de Gruyter, 692-786.

ZIMMERMANN, Malte (2011) "Discourse particles." In: C. Maienborn et al. (eds), Handbooks of Linguistics and Communication Science (HSK) 33/2. Berlin/New York: DeGruyter, 2012-2038.

Corpus: ZEIT corpus of the DWDS online platform, http://dwds.de/

Summary

CONDITIONAL ANTECEDENTS CONTAINING THE GERMAN DISCOURSE PARTICLE DENN: A CORPUS STUDY

We discuss the semantic contribution and distribution of conditional antecedents containing the discourse particle denn ("antecedents with denn", abbreviated as AWD). We propose that AWDs occur only in contexts where (i) the speaker does not believe the antecedent proposition $p$ to hold, and (ii) the truth of $p$ has been nonexplicitly (= tacitly) proposed. To gain a better understanding of (ii), we conduct two 
corpus studies. The first study investigates the relative location of AWDs with respect to their consequents. We find that unlike antecedents of regular hypothetical conditionals, AWDs occur significantly more often after the material in the consequent and parenthetically inside this material than before it. In a second study, we investigate the position of the tacit proposal relative to the AWD. We find that it typically precedes the AWD. Both results are in accordance with (ii). We then present a classification of the types of tacit proposals that we find with AWDs: speakers use AWDs to qualify their own statements or to doubt proposals of others, in both cases managing potential updates to the common ground.

Keywords: conditional antecedents, German, discourse particles, denn, corpus study

\section{Povzetek \\ NEMŠKI POGOJNI ODVISNIKI Z DISKURZNIM ČLENKOM DENN: KORPUSNA ANALIZA}

Članek obravnava rabo in pomen nemških pogojnih odvisnikov, ki vsebujejo diskurzni členek denn (odvisniki z denn). V članku predlagamo, da se odvisniki z denn rabijo le $\mathrm{v}$ tistih kontekstih, $\mathrm{v}$ katerih (i) govorec ne verjame $\mathrm{v}$ resničnost propozicije $p$ in (ii) je resničnostna vrednost propozicije $p$ zgolj implicirana. Da bi bolje razumeli slednji kontekst, smo izvedli dve korpusni analizi. V prvi smo se osredinili na položaj odvisnika glede na glavni stavek. Analiza je pokazala, da se odvisniki z denn v nasprotju z navadnimi hipotetičnimi odvisniki signifikantno bolj pogosto pojavljajo bodisi za glavnim stavkom bodisi kot vrivek znotraj glavnega stavka kot pa pred glavnim stavkom. V drugi smo proučili relativni položaj konteksta, ki implicira resničnostno vrednost propozicije, glede na položaj odvisnika z denn. Podatki pokažejo, da se le-ta pojavlja praviloma pred odvisnikom z denn. Oba rezultata sta skladna z (ii). Na koncu predstavimo klasifikacijo kontekstov, ki implicirajo resničnostno vrednost propozicije in omogočajo rabo odvisnikov z denn. Govorci uporabljajo odvisnike z denn, da kvalificirajo lastne izjave ali da izrazijo dvom do izjav drugih in tako preprečijo, da bi bila propozicija $p$ sprejeta kot resnična.

Ključne besede: pogojni odvisniki, nemščina, diskurzni členki, denn, korpusna analiza 